\title{
PENGARUH LEMBAR KERJA PESERTA DIDIK (LKPD) BERBASIS INKUIRI TERBIMBING TERHADAP KETERAMPILAN PROSES SAINS PESERTA DIDIK KELAS XI SMAN 8 MAKASSAR
}

\section{EFFECT OF STUDENT WORKSHEETS BASED ON GUIDED INQUIRY ON SCIENCE PROCESS SKILLS STUDENTS CLASS XI SMAN 8 MAKASSAR}

\author{
${ }^{1)}$ Monalisa Islami, ${ }^{2)}$ Khaeruddin, ${ }^{3)}$ Aisyah Azis \\ Universitas Negeri Makassar \\ Kampus UNM Parangtambung Jln. Daeng Tata Raya, Makassar, 90224 \\ ${ }^{1)}$ e-mail : monalisaislami96@gmail.com
}

\begin{abstract}
Effect Of Student Worksheets Based On Guided Inquiry On Science Process Skills Students Class Xi Sman 8 Makassar. This research is a Quasi experimental study which aims to find out the science process skills in physics learning of students taught by guided inquiry learning and conventional learning, as well as to find out whether there are significant differences in science process skills in physics learning between students taught using inquiry guided and students taught using conventional models. The population in this study were all students of class XI of SMA Negeri 8 Makassar which consisted of six classes with 240 students, sampling was done by random sampling of the six classes of MIPA, which were selected as experimental class namely class XI MIPA 2 taught using guided inquiry learning and the control class that is class XI MIPA 1 taught using conventional learning models. Based on the descriptive analysis, it was found that the science process skills in the experimental class were in the very high category while the control class was in the low category. The results of the hypothesis test analysis indicate that there is a significant difference between the science process skills of students who are taught with guided inquiry learning and students who are taught using conventional models at the significance level $\alpha=0.05$.
\end{abstract}

Keywords : Guided Inquiry Learning Model, Science Process Skills..

\begin{abstract}
Abstrak. Pengaruh Lembar Kerja Peserta Didik (Lkpd) Berbasis Inkuiri Terbimbing Terhadap Keterampilan Proses Sains Peserta Didik Kelas Xi Sman 8 Makassar. Penelitian ini adalah penelitian Quasi eksperimen yang bertujuan untuk mengetahui keterampilan proses sains dalam pembelajaran fisika peserta didik yang diajar dengan pembelajaran inkuiri terbimbing dan pembelajaran konvensional, serta untuk mengetahui apakah terdapat perbedaan yang signifikan terhadap keterampilan proses sains dalam pembelajaran fisika antara peserta didik yang diajar menggunakan inkuiri terbimbing dan peserta didik yang diajar menggunakan model konvensional. Populasi dalam penelitian ini adalah seluruh peserta didik kelas XI SMA Negeri 8 Makassar yang terdiri dari enam kelas dengan jumlah peserta didik 240, pengambilan sampel dilakukan secara random sampling dari enam kelas MIPA, yang terpilih sebagai kelas eksperimen yaitu kelas XI MIPA 2 yang diajar dengan menggunakan pembelajaran inkuiri terbimbing dan kelas kontrol yaitu kelas XI MIPA 1 diajar menggunakan model pembelajaran konvensional. Berdasarkan analisis deskriptif diperoleh bahwa keterampilan proses sains pada kelas eksperimen berada pada kategori sangat tinggi sedangkan pada kelas control pada kategori rendah. Hasil analisis uji hipotesis menunjukkan bahwa terdapat perbedaan yang signifikan antara keterampilan proses sains peserta didik yang diajar dengan pembelajaran inkuiri terbimbing dan peserta didik yang diajar dengan menggunakan model konvensional pada taraf nyata $\alpha=0,05$.
\end{abstract}

Kata kunci : Model Pembelajaran Inkuiri Terbimbing, Keterampilan Proses Sains

\section{PENDAHULUAN}

Pendidikan merupakan salah satu hal yang penting yang dapat mewujudkan sumber daya manusia berkualitas dan diperlukan oleh suatu bangsa agar mampu bersaing serta berkompetensi den gan bangsa lain. Oleh sebab itu, untuk mewujudkan suatau pendidikan yang kualitas, pendidikan tidak hanya dipandang sebagai pemberian informasi saja tetapi ditekankan pada pemrosesan informasi sehingga tidak hanya penguasaan materi yang tercapai tetapi aspek keterampilan individu juga dapat tercapai. Untuk dapat menunjang keberhasilan proses pembelajaran, maka diperlukan kemempuan pendidik dalam mengembangkan model pembelajaran yang efektif. 
Proses pembelajaran selama ini yang diberlakukan disekolah yaitu berpusat pada pendidik. Hal ini dapat dilihatkan kegiatan pembelajaran yang hanya didominasi oleh pemindahan pengetahuan dari pendidik kepeserta didik sehingga kurang memberikan peluang bagi peserta didik untuk mengembangkan kemempuan berfikir dan menunjukkan kemampuan yang beragam untuk terciptanya suasana belajar yang efektif.

Pada kenyataannya mutu pendidikan di Indonesia masih tergolong rendah khususnya pada pembelajaran sains. Hal ini dapat dilihat dari Trends in Internasional Mathematics and Science Study (TIMSS) tahun 2015 menurut Kemdikbud bahwa literasi sains khususnya fisika, Indonesia berada di urutan ke 45 dari 48 negara dengan pencapaian skor 397 dan masih di bawah skor rata-rata internasional yaitu 500. Bahkan dari hasil studi yang dilakukan Programme for Internasional Students Assesment (PISA) di tahun 2015 lalu Indonesia berada di urutan ke 69 dari 76 negara (BBC, 2015). Di tahun 2012 bahwa Indonesia berada di peringkat rendah yaitu di peringkat 64 dari 65 negara (OECD, 2013). Hal ini menunjukan bahwa prestasi siswa Indonesia di bidang sains masih rendah.

Rendahnya mutu pendidikan di Indonesia, khususnya pembelajaran sains salah satu penyebabnya adalah pembelajaran sains tidak diajarkan sesuai dengan karakteristik sains itu sendiri. Asminah (2010) menyatakan salah satu faktor kurang berhasilnya pembelajaran tidak sesuai dengan mata pelajaran fisika, guru kurang mengaktifkan siswa sehingga siswa hanya sebagai pendengar saja sehingga berakibat kreativitas siswa terabaikan.

Fisika dikelompokkan sebagai pengetahuan fisis. Oleh karena fisika adalah pengetahuan fisis, maka sangat jelas bahwa untuk mempelajari fisika dan membentuk pengetahuan tentang fisika, diperlukan kontak langsung dengan hal yang ingin diketahui. Inilah sebabnya dalam fisika terdapat eksperimen, dimana siswa dapat mengamati, mengukur, mengumpulkan data, menganalisa data, dan menyimpulkan sangat cocok dalam mempelajari fisika (Suparno, 2007).

Pembelajaran sains khususnya fisika harus diajarkan sesuai dengan karakteristik fisika melalui pengukuran langsung, penggunaan metode eksperimen, demonstrasi dan penjabaran rumus. Mata pelajaran fisika di SMA dikembangkan untuk mendidik siswa agar mampu mengembangkan observasi dan eksperimentasi serta berpikir taat asas. Berpikir taat asas dikembangkan dari kemampuan matematis yang dimiliki lewat pelajaran matematika. Kemampuan observasi dan eksperimentasi ditekankan pada melatih kemampuan berpikir eksperimental. Kemampuan berpikir eksperimental mencakup tata laksana eksperimen dan mengenal peralatan laboratorium.

Hasil wawancara dengan guru menunjukkan bahwa pengajaran fisika di SMAN 8 Makassar biasanya guru membuka pembelajaran dengan memberi motivasi awal pentingnya belajar fisika dikaitkan dengan aplikasi sederhana dalam kehidupan sehari-hari sesuai materi yang diajarkan. Setelah itu guru memberi materi kepada siswa lalu disertai beberapa contoh soal dan latihan soal agar siswa lebih paham mengenai materi fisika yang diajarkan tersebut. Hal demikian di atas menunjukan bahwa pembelajaran fisika di SMAN 8 Makassar masih cenderung menekankan guru berpusat sebagai sumber informasi pembelajaran. Kondisi serupa dengan yang dikatakan Zulfatin (2014) bahwa pada umumnya guru dalam pembelajaran sains banyak menekankan pemberian informasi serta enggan melaksanakan kegiatan pembelajaran dengan melakukan kegiatan di laboratorium. Hal tersebut dapat 
disebabkan berbagai faktor diantaranya adalah kurangnya fasilitas alat laboratorium yang dapat mendukung pembelajaran menggunakan eksperimen.

Banyak model, metode atau pendekatan pembelajaran yang dapat diterapkan yang sesuai dengan tujuan mata pelajaran fisika. Salah satunya adalah metode eksperimen. Menurut Rafika (2009) metode eksperimen merupakan metode yang sesuai untuk pembelajaran sains, karena metode eksperimen dapat mengembangkan kemampuan berfikir dan kreatif secara optimal. Menurut Hadma dkk (2012) bahwa metode yang sesuai dengan karakteristik mata pelajaran fisika adalah metode eksperimen.

Peserta didik dalam metode eksperimen dapat melakukan suatu percobaan tentang suatu hal, mengamati prosesnya, serta menuliskan hasil percobaannya, merumuskan hipotesis berdasarkan hasil pengamatannya, melalui verifikasi terhadap dugaan sementaranya yang telah dirumuskan dan melalui kerja kelompok. Eksperimen merupakan salah satu metode yang sering digunakan pada pembelajaran fisika dengan melibatkan peserta didik secara langsung dalam kegiatan praktikum. Pada pelaksanaan suatu percobaan dilakukan dengan bantuan LKPD. LKPD adalah salah satu sumber belajar yang digunakan oleh peserta didik untuk memperoleh informasi mengenai materi yang dipelajari melalui kegiatan yang dilakukan secara sistematis. Wahyuningsih mengungkapkan LKPD yang tersedia di pasaran tidak mengacu pada kurikulum yang berlaku saat ini, yaitu Kurikulum 2013. LKPD umumnya hanya berisi ringkasan materi, contoh soal dan dilanjutkan dengan evaluasi sehingga tidak mengacu pada kegiatan ilmiah. Adapun LKPD yang terdapat kegiatan praktikum hanya berisi instruksi langsung sehingga siswa melakukan praktikum sesuai instruksi yang terdapat dalam LKPD tanpa memikirkan alasan pengerjaan tahap demi tahap yang dilakukan. Pada beberapa LKPD juga tidak ditemukan adanya contoh penerapan konsep dalam kehidupan sehari-hari. Selain itu, LKPD juga tidak dilengkapi dengan warna, gambar, peta konsep dan bahasa yang digunakan kurangkomunikatif. Berdasarkan hasil observasi yang dilakukan oleh peneliti di SMAN 8 Makassar di ketahui bahwa LKPD eksperimen yang digunakan oleh peserta didik dalam pembelajaran fisika masih LKPD berbasis konvensional. LKPD berbasis konvensional merupakan LKPD yang memberikan informasi kerja berupa petunjuk atau instruksi yang harus dilakukan oleh peserta didik. LKPD tersebut biasanya memuat ringkasan materi, soal-soal latihan dan terdapat prosedur praktikum namun susunannya kurang memenuhi tuntutan kurikulum 2013 dimana peserta didik yang menemukan sendiri suatu konsep. Selain itu LKPD konvensional bahasa yang sulit dipahami dan desain LKPD kurang menarik bagi peserta didik serta tidak menuntun peserta didik dalam melakukan langkah-langkah keterampilan proses sains yang membuat peserta didik menemukan sendiri fakta atau konsep fisika, sehingga LKPD tersebut kurang efektif dalam meningkatkan keterampilan proses sains peserta didik.

Menurut penelitian yang dilakukan oleh Magfira dkk. (2017) menunjukkan bahwa tingkat kemampuan keterampilan proses sains peserta didik SMA Negeri 8 Makassar berada pada kategori sedang, dimana berdasarkan hasil penelitiannya diperoleh n-gain sebesar 0,31. Berdasarkan penelitian yang dilakukan oleh Kholifah (2017) penggunaan LKPD berbasis guided inquiry efektif untuk meningkatkan keterampilan proses sains karena terjadi peningkatan keterampilan proses sains. LKPD berbasis inkuiri merupakan LKPD yang dapat melatih keterampilan proses sains peserta didik karena dalam langkah-langkah inkuiri terdapat komponen keterampilan proses sains yang ingin 
ditingkatkan. Oleh karena itu perlu diketahui seberapa efektif LKPD berbasis inkuiri ini dalam meningkatkan keterampilan proses sains peserta didik.

Permasalahan yang sering ditemui dalam proses pembelajaran fisika juga adalah asumsi para peserta didik yang manyatakan fisika itu tergolong mata pelajaran yang sulit. Dimana proses pembelajaran fisika lebih menekankan pada perumusan matematis dan teori yang membutuhkan pembimbingan lebih untuk diajarkan kepada peserta didik seperti pada permasalahan sekolah yang dituju pada penelitian ini yakni SMA Negeri 8 Makassar merupakan salah satu sekolah negeri di kota Makassar. Berdasarkan penerapan diatas, peneliti juga telah melakukan penelitian pada proses pembelajaran dengan menerapkan model inkuiri terbimbing yang berlangsung pada kelas XI SMA Negeri 8 Makassar. Adapun judul yang diangkat peneliti yaitu "Pengaruh Lembar Kerja Peserta Didik (LKPD) Berbasis Inkuiri Terbimbing terhadap Keterampilan Proses Sains Peserta Didik Kelas XI SMA Negeri 8 Makassar".

\section{METODE}

Penelitian ini menggunakan jenis penelitian kuantitatif metode eksperimen. Metode penelitian eksperimen merupakan metode penelitian yang digunakan untuk mencari pengaruh treatment tertentu dalam kondisi yang terkontrol. Penelitian ini telah dilaksanakan di SMA Negeri 8 Makassar pada peserta didik kelas XI IPA tahun ajaran 2018/2019 yaitu pada semester ganjil bulan September 2018. Variabel dalam penelitian ini adalah LKPD berbasis inkuiri terbimbing, LKPD pembelajaran konvensional dan keterampilan proses sains, Adapun desain penelitian yaitu menggunakan metode Quasi Eksperimen menggunakan Posttest Only Nonequivalent ControlGroupDesign. Dalam Posttest-Only control Desain terdapat dua kelompok yang masing-masing dipilih secara acak atau random. Kelompok pertama diberi perlakuan (X) dan kelompok yang lain tanpa perlakuan. Kelompok yang mendapat perlakuan disebut kelas experimen, sedangkan kelompok yang tidak mendapat perlakuan disebut kelas kontrol. Adapun pengaruh atau tidak adanya perlakuan adalah $\mathrm{O}_{1}: \mathrm{O}_{2}$ (Sugiyono,2015:502).

Populasi dalam penelitian ini adalah semua peserta didik kelas XI MIPA SMA Negeri 8 Makassar Tahun Ajaran 2018/2019. Yang terdiri dari enam kelas dengan jumlah 240 peserta didik. Pengambilan sampel dalam penelitian ini menggunakan teknik random sampling, yaitu pengambilan sampel yang dilakukan secara acak dengan asumsi semua kelas memiliki karakteristik yang homogen. Hasil dari pengambilan sampel ditetapkan kelas eksperimen (XI MIPA 2) dan kelas kontrol (XI MIPA 1) dengan jumlah peserta didik pada kelas eksperimen yaitu 35 dan peserta didik pada kelas kontrol yaitu 35. Pada kelompok eksperimen diterapkan model pembelajaran inkuiri terbimbing, sedangkan kelas kontrol model pembelajaran konvensional. Instrumen yang digunakan untuk mengumpulkan data pada penelitian ini adalah tes hasil belajar. Tes hasil belajar berisi butir soal pilihan ganda dibuat berdasarkan materi yang akan diajarkan pada saat penelitian. Soal-soal yang telah dibuat dan dikonsultasikan dengan dosen pembimbing selanjutnya akan dilakukan uji validitas Gregory atau uji validitas isi. Uji validitas Gregory merupakan pengujian valid atau tidaknya suatu instrumen yang dilakukan oleh dua atau lebih pakar/ahli. Selain uji validitas, dilakukan pula uji reliabilitas. Reliabilitas tes merupakan ukuran sejauh mana alat ukur atau instrumen tersebut memberikan gambaran yang benar-benar dapat dipercaya tentang kemampuan seseorang. Reliabilitas tes dapat pula diartikan sebagai ketepatan atau keandalan alat ukur yang merujuk pada konsistensi dalam mengukur apa yang 
hendak di ukur. Untuk mengetahui reliabilitas item soal digunakan metode Kuder-Richardson20(KR-20).

Teknik analisis data yang akan digunakan dalam penelitian ini yaitu dengan menggunakan teknik statistik yaitu statistik deskriptif untuk menguji pertanyaan penelitian yang diajukan. Analisis ini dimaksudkan untuk mendeskripsikan keterampilan proses sains peserta didik setelah diterapkan metode eksperimen. Hal ini dimaksudkan untuk mengetahui jumlah sampel, skor tertinggi, skor terendah, skor rata-rata, standar deviasi, variansi serta penyusunan urutan kategori yang dihitung dengan program Microsoft excel.

Tabel 1. Pengkategorian Skor Keterampilan Proses Sains

\begin{tabular}{cl}
\hline $\begin{array}{r}\text { Persentase } \\
\text { Interval Skor }(\%)\end{array}$ & Kriteria \\
\hline $90-100$ & Baik sekali \\
$79-89$ & Baik \\
$69-78$ & Cukup \\
$58-68$ & Kurang \\
$0-57$ & Kurang sekali \\
\hline
\end{tabular}

(Sudijono, 2015)

\section{HASIL DAN PEMBAHASAN}

Hasil analisis deskriptif menunjukkan deskripsi tentang karakteristik distribusi skor Keterampilan Proses Sains dari masing-masing kelompok penelitian dan sekaligus sebagai masalah yang dirumuskan dalam penelitian ini.
Adapun gambaran skor keterampilan proses sains fisika peserta didik antara dua kelas yaitu diajar dengan model pembelajaran inkuiri terbimbing dan kelas control yang diajar dengan model pembelajaran konvensional adalah sebagai berikut:

Tabel 2. Skor statistik deskriptif keterampilan proses sains fisika peserta didik kelas eksperimen dan kelas control kelas XI SMAN 8 Makassar

\begin{tabular}{lcc}
\hline \multicolumn{1}{c}{ Statistik } & $\begin{array}{c}\text { Kelas Ekperimen } \\
\text { Posttest }\end{array}$ & $\begin{array}{c}\text { Kelas Kontrol } \\
\text { Posttest }\end{array}$ \\
\hline Ukuran sampel & 35 & 35 \\
Skor tertinggi & 13 & 12 \\
Skor terendah & 7 & 5 \\
Skor ideal & 13 & 13 \\
Skor rata-rata $(\bar{x})$ & 11.17 & 9.48 \\
Standar deviasi $(\mathrm{s})$ & 3,04 & 1,36 \\
Varians $\left(\mathrm{s}^{2}\right)$ & 9,21 & 1,85 \\
\hline
\end{tabular}

Table 2 diatas kelas eksperimen menunjukkan skor rata-rata peserta didik 11.17 sedangkan kelas kontrol menunjukkan skor 9.48 dimana skor rata-rata yang di peroleh pada kelas eksperimen lebih tinggi dibanding kelas kontrol. Sedangan untuk skor varians pada kelas eksperimen menunjukkan skor 9,21 sedangkan kelas kontrol dicapai hanya 1,85 untuk post test. 
Tabel 3. Distribusi Frekuensi Dan Persentasi Skor Keterampilan Proses Sains Fisika Peserta Didik

\begin{tabular}{|c|c|c|c|c|c|c|}
\hline \multirow{2}{*}{ No. } & \multicolumn{2}{|l|}{ Interval } & \multicolumn{2}{|c|}{ Posttest Eksperimen } & \multicolumn{2}{|c|}{ Posttest Kontrol } \\
\hline & $\begin{array}{l}\text { Skor } \\
(\%)\end{array}$ & Kategori & Frekuensi & $\begin{array}{c}\text { Presentase } \\
(\%)\end{array}$ & Frekuensi & $\begin{array}{c}\text { Persentase } \\
(\%)\end{array}$ \\
\hline 1 & $90-100$ & Baik sekali & 15 & 42.86 & 1 & 2.86 \\
\hline 2 & $79-89$ & Baik & 13 & 37.14 & 7 & 20.00 \\
\hline 3 & $69-78$ & Cukup & 5 & 14.29 & 20 & 57.14 \\
\hline 4 & $58-68$ & Kurang & 1 & 2.86 & 5 & 14.29 \\
\hline 5 & $0-57$ & $\begin{array}{l}\text { Kurang } \\
\text { sekali }\end{array}$ & 1 & 2.86 & 2 & 5.71 \\
\hline & mlah & - & 35 & 100 & 35 & 100 \\
\hline
\end{tabular}

Tabel 3 di atas menunjukkan bahwa pada post tes dari 35 peserta didik yang menjadi subjek penelitian, persentase skor keterampilan proses sains kelas eksperimen yang berada pada kategori baik sekali yaitu $42,86 \%$ sedangkan persentase skor keterampilan proses sains kelas kontrol yang berada pada kategori baik sekali yaitu 2,86\% artinya untuk kelaas eksperimen persentase skor keterampilan proses sains lebih besar dibanding kelas kontrol untuk kategori sangat tinggi. Sedangkan persentase skor keterampilan proses sains untuk kategori kurang pada kelas eksperimen yaitu $2,86 \%$ dan untuk kelas kontrol yaitu $14,29 \%$ artinya untuk kelas eksperimen persentase skor keterampilan proses sains lebih kecil dibanding kelas kontrol untuk kategori rendah. Hal ini mengindikasikan bahwa distribusi frekuensi skor keterampilan proses sains fisika pada kelas eksperimen mengalami peningkatan dimana keterampilan proses sains dari kategori baik ke kategori baik sekali dan untuk kelas kontrol mengalami peningkatan persentase keterampilan proses sains dari kategori kurang ke kategori cukup.

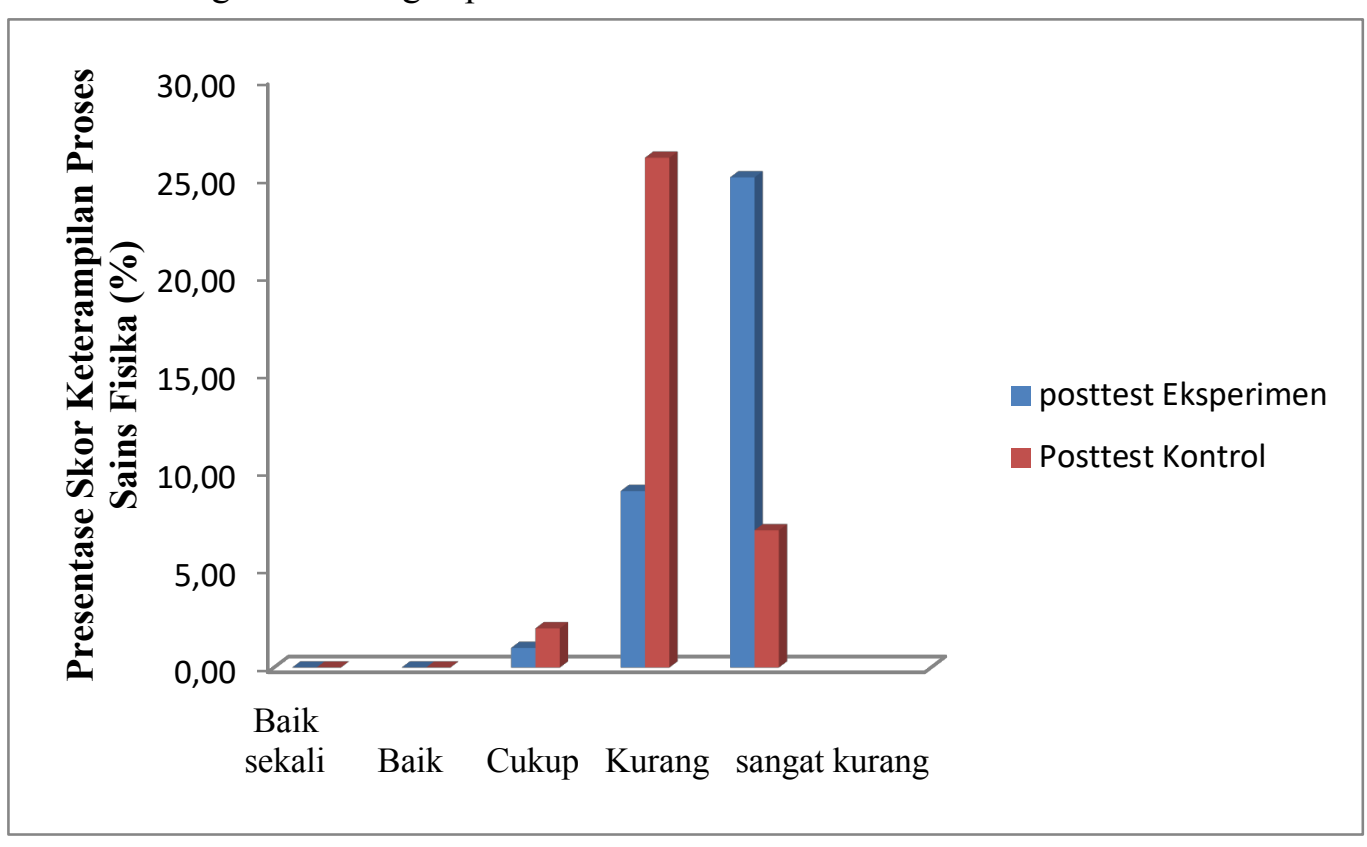

Grafik 1. Distribusi Presentase Frekuensi Skor Keterampilan Proses Sains Fisika Pada Kelas Eksperimen Dan Kontrol 
Tabel 4. Gambaran Keterampilan Proses Sains Peserta Didik Setiap Indikator kelas eksperimen

\begin{tabular}{lcccc}
\hline $\begin{array}{c}\text { Indikator Keterampilan } \\
\text { Proses sains }\end{array}$ & $\begin{array}{c}\text { Skor } \\
\text { Rata-rata }\end{array}$ & $\begin{array}{c}\text { Skor } \\
\text { Ideal }\end{array}$ & $\begin{array}{c}\text { Persentase } \\
\mathbf{( \% )}\end{array}$ & Kategori \\
\hline Mengamati & 1 & 1 & 100 & Baik sekali \\
Mengklasifikasi & 0,9 & 1 & 90 & Baik sekali \\
Menafsirkan & 1.8 & 2 & 90 & Baik sekali \\
Memprediksi & 1,7 & 2 & 87 & Baik \\
Mengajukan pertanyaan & 0,9 & 1 & 90 & Baik sekali \\
Hipotesis & 0.54 & 1 & 54 & Kurang sekali \\
Merancang percobaan & 0,77 & 1 & 77,14 & Cukup \\
Menggunakan alat dan bahan & 0,82 & 1 & 83 & Baik \\
Mengkomunikasikan & 1,8 & 2 & 90 & Baik sekali \\
Menerapkan konsep & 0,88 & 1 & 88 & Baik \\
\hline
\end{tabular}

Tabel 4. diatas menunjukkan bahwa skor kurang sekali dan cukup yaitu indikator hipotesis keterampilan proses sains untuk setiap indikator dan merancang perocbaan, artinya pada kelas memiliki nilai yang baik sekali, dimana hanya dua eksperimen nilai rata-rata peserta didik berada indikator yang kategori skornya berada pada taraf pada kategori baik sekali.

Tabel 5. Gambaran Keterampilan Proses Sains Peserta Didik Setiap Indikator Kelas Kontrol

\begin{tabular}{lcccc}
\hline $\begin{array}{c}\text { Indikator Keterampilan } \\
\text { Proses sains }\end{array}$ & $\begin{array}{c}\text { Skor } \\
\text { Rata-rata }\end{array}$ & $\begin{array}{c}\text { Skor } \\
\text { Ideal }\end{array}$ & $\begin{array}{c}\text { Persentase } \\
\mathbf{( \% )}\end{array}$ & Kategori \\
\hline Mengamati & 0,77 & 1 & 38,5 & Kurang sekali \\
Mengklasifikasi & 0,77 & 1 & 38,5 & Kurang sekali \\
Menafsirkan & 1.48 & 2 & 74 & Cukup \\
Memprediksi & 1,37 & 2 & 68,57 & Cukup \\
Mengajukan pertanyaan & 0,8 & 1 & 80 & Baik \\
Hipotesis & 0.54 & 1 & 54 & Kurang sekali \\
Merancang percobaan & 0,6 & 1 & 60 & Kurang \\
Menggunakan alat dan bahan & 0,77 & 1 & 77,14 & Cukup \\
Mengkomunikasikan & 1,62 & 2 & 81,42 & Baik \\
Menerapkan konsep & 0,74 & 1 & 74,28 & Cukup \\
\hline
\end{tabular}

Tabel 4.4 diatas menunjukkan bahwa skor keterampilan proses sains untuk sebagian besar indikator memiliki nilai yang kurang sekali dan cukup, dimana hanya dua indikator yang kategori skornya berada pada taraf Baik yaitu indikator mengajukan pertanyaan dan mengkomunikasikan, artinya pada kelas eksperimen nilai rata-rata peserta didik berada pada kategori kurang.

Sebelum hipotesis yang ajukan dalam penelitian ini terlebih dahulu dilakukan dasardasar analisis yang merupakan syarat dalam 
pemakaian statistik pengujian dasar-dasar analisis tersebut meliputi:

Uji normalitas dilakukan untuk mengetahui apakah data yang diperoleh berasal dari populasi yang terdistribusi atau tidak. Teknik pengujian normalitas data keterampilan proses sains peserta didik dilakukan menggunakan hasil uji SPSS dimana nilai sig $(0,001)$ untuk kelas eksperimen sedangkan nilai sig $(0,004)$ untuk kelas control, sehingga dapat dikatakan sig $(0,001)<\operatorname{sig}(0,004)$ maka tidak terdapat data yang normal sehingga di gunakan uji Non parametrik dengan Maan Whitney dapat dilihat pada (Lampiran B.5). Uji Homogetitas dilakukan untuk mengetahui apakah data yang diteliti memiliki varians yang homogen atau tidak dengan menggunakan uji SPSS. kriteria pengujian, jika $s i g_{1}<s i g_{2}$ maka varians kelas eksperimen dengan varians kelas kontrol bersifat homogen. Berdasarkan uji homogenitas dengan menggunakan varians kelas eksperimen sebagai varians terbesar dan kelas kontrol sebagai varians terkecil diperoleh nilai $s i g_{1}=0,166$ dan $s i g_{2}=$ 0,685 sehingga data tersebut Homogen, dapat dilihat pada (Lampiran B.5). Pengujian hipotesis dapat digunakan dengan dua metode yaitu metode parametrik dan non-parametrik, karena hasil penelitian yang diperoleh peneliti tidak terdistribusi normal maka digunakan metode nonparametrik dengan menggunakan uji-U (Tes Mann Whitneyy). Uji Mann Whitneyy dilakukan untuk mengetahui ada tidaknya pengaruh pembelajaran berbasis inkuiri terbimbing terhadap keterampilan proses sains peserta didik. Dari data (lapiran B.5) dapat dilihat signifikasinya dibawah 0,05 sehingga terdapat pengaruh peserta didik kelas Eksperimen dan kelas Kontrol.

Penelitian yang telah dilakukan dimaksudkan untuk mengetahui pengaruh lembar kerja peserta didik (LKPD) berbasis inkuiri terbimbing terhadap keterampilan proses sains peserta didik kelas XI SMAN 8 Makassar. Dimana
LKPD yang dilaksanakan oleh peneliti adalah LKPD inkuiri terbimbing. LKPD inkuiri terbimbing biasanya digunakan untuk peserta didik yang belum terbiasa dengan LKPD inkuiri atau digunakan untuk peserta didik yang baru beralih dari pembelajaran konvensional.

LKPD berbasis inkuiri merupakan LKPD yang dapat melatih keterampilan proses sains peserta didik karena dalam langkah-langkah inkuiri terdapat komponen keterampilan proses sains yang ingin ditingkatkan. Oleh karena itu perlu diketahui seberapa efektif LKPD berbasis inkuiri ini dalam meningkatkan keterampilan proses sains peserta didik, adapun bahan ajar yang diberikan pendidik sebagai sarana untuk memecahkan suatu masalah yang berisi pentunjuk dan pemberian soal dalam hal ini guru hanya sebagai vasilitator selebihnya peserta didik dituntut untuk menemukan pemecahan masalah itu sendiri, sedangkan LKPD berbasis konvensional merupakan LKPD yang memberikan informasi kerja berupa petunjuk atau instruksi yang harus dilakukan oleh peserta didik. LKPD tersebut biasanya memuat ringkasan materi, soal-soal latihan dan terdapat prosedur praktikum namun susunannya kurang memenuhi tuntutan kurikulum 2013 dimana peserta didik yang menemukan sendiri suatu konsep. Selain itu LKPD konvensional bahasa yang sulit dipahami dan desain LKPD kurang menarik bagi peserta didik serta tidak menuntun peserta didik dalam melakukan langkah-langkah keterampilan proses sains yang membuat peserta didik menemukan sendiri fakta atau konsep fisika, sehingga LKPD tersebut kurang efektif dalam meningkatkan keterampilan proses sains peserta didik.

Pada sekolah yang peneliti tujuh saat observasi di sekolah tersebut, ternyata peserta didik tidak pernah melakukan praktikum selama belajar fisika, artinya untuk keterampilan proses sains masih tergolong rendah sehingga perlu dilakukan praktikum pada peserta didik. Hal ini penting 
diberi perhatian khusus karena akan menyebabkan tidak tumbuhnya keterampilan proses sains dan keterampilan lain seperti berfikir kritis pada peserta didik. Oleh sebab itu pada penelitian ini digunakan model pembelajaran inkuiri terbimbing harapan ditemukannya pengaruh model tersebut terhadap keterampilan proses sains. Sebagaimana penekanan pembelajaran sains yakni pemberian pengalaman secara langsung untuk mengembangkan kompetensi menjelajahi dan memahami alam sekitar secara alami penekanan tersebut diharapkan dapat meningkatkan kemampuan peserta didik. Peneliti dalam penelitian ini mengambil dua kelas sebagai kelompok sampel yakni kelas eksperimen dan kelas kontrol agar mampu mengetahui pengaruh LKPD inkuiri terbimbing terhadap keterampilan proses sains peserta didik. Kelas eksperimen yakni kelas yang diajarkan menggunakan LKPD inkuiri terbimbing yang harapannya mampu memengaruhi keterampilan proses sains peserta didik seperti yang ditunjukan pada Tabel 4.2 yaitu frekuensi dan prestasi skor keterampilan proses sains peserta didik. Keterampilan tersebut akan dimiliki peserta didik melakukan kegiatan pembelajaran secara sistematik dan analisis, sedangkan untuk kelas kontrol digunakan LKPD yang diterapkan oleh guru yang ada pada sekolah tersebut yaitu LKPD konvensional yang lebih dominan pemberian tugas di kelas.

Berdasarkan analisis deskriptif terlihat bahwa skor rata-rata secara keseluruhan keterampilan proses sains untuk kelas eksperimen dan kelas kontrol yaitu 11,17 dengan kategori baik dan 9,48 dengan skor ideal yaitu 13 seperti yang ditunjukkan pada tabel 4.1 skor statistik dskriptif keterampilan proses sains fisika peserta didik. Pada kelas eksperimen berkumpul di kategori baik sekali dengan persentase $42,86 \%$ sedangkan untuk kelas kontrol dikategori baik sekali dengan persentase $2,86 \%$ seperti yang ditunjukkan pada
Tabel 4.2 distribusi frekuensi dan persentasi skor ketrampilan proses sains peserta didik.

Penyebab dari perbedaan yang cukup signifikan yaitu disebabkan karena pada kelas eksperimen menggunakan model pembelajaran inkuiri terbimbing, sehingga peserta didik menerima informasi dan konsep pembelajaran pemberian buku bacaan (buku siswa) yang dilengkapi dengan contoh bagaimana merumuskan masalah dan menentukan variable, melihat alat-alat ukur pada saat praktikum, serta LKPD sehingga peserta didik dapat melatih keterampilan proses sainsnya. Sedangkan pada kelas kontrol peserta didik diajar oleh gurunya dengan LKPD konvensional dimana dalam proses pembelajaran hanya berpusat pada pendidik yang sebagai sumber informasi dan peserta didik hanya sebagai pendengar dan mengerjakan contoh soal serta latihan yang diberikan oleh pendidik. Hal ini sesuai dengan penelitian yang pernah dilakukan oleh Wiwin, dkk (2013), dimana dalam penelitiannya menemukan bahwa pembelajaran inkuiri terbimbing memberikan pengaruh yang signifikan terhadap keterampilan proses sains karena pembelajaran inkuiri terbimbing tersebut melibatkan proses secara ilmiah melalui eksperimen untuk membuktikan kebenaran suatu materi yang dipelajari.

Pada kelas eksperimen peserta didik telah diajarkan cara menganalisis yaitu menganalisis data percobaan dan beberapa soal latihan pada LKPD yang diberikan yang tahap soalnya sampai tahap menganalisis. Namun, pada proses pembelajaran ketika peserta didik selesai melakukan percobaan dan masuk ketahap menganalisis, peserta didik hampir seluruhnya kebingungan, sehingga peneliti harus mengajarkan setiap kelompok secara bergantian bagaimana cara menganalisis data yang mereka peroleh. Waktu yang dibutuhkan dalam menganalisis hanya sedikit karena peserta didik 
terlalu focus dalam proses sains yang dilakukan, sehingga peneliti hanya menjelaskan secara singkat bagaimana menganalisis dan selebihnya peserta didik yang mengerjakan. Sedangkan proses pembelajaran pada kelas kontrol selalu diberikan latihan soal oleh gurunya sehingga mereka terbiasa dalam mengerjakan soal meskipun soal tersebut telah mencapai tahap menganalisis.

Perbedaan yang nyata antara kelas eksperimen dan kelas kontrol adalah suasana kelas ketika proses pembelajaran berlangsung. Peserta didik pada kelas eksperimen lebih aktif dalam proses pembelajaran dimana ketika peneliti sebagai pendidik menjelaskan dikelompok lain tentang materi yang dipelajari, terdapat beberapa peserta didik dari kelompok lain yang ikut mendengarkan penjelasan yang disampaikan peneliti selain itu, juga terdapat peserta didik yang berkunjung pada kelompok lain untuk bertanya tentang apa yang mereka belum pahami, sehingga peserta didik tidak monoton didalam kelas. Pembelajaran inkuiri terbimbing juga menyediakan waktu bagi peserta didik untuk memperoleh pengalaman belajar langsung. Berbeda dengan kelas kontrol peserta didik pada kelas tersebut hanya duduk menerima informasi dan fokus mengerjakan latihan soal-soal pada LKPD yang diberikan. Sebagaimana pendapat Sutama, dkk (2014) yang menyatakan bahwa keaktivan siswa dalam proses pembelajaran akan menciptakan interaksi yang intensif antara guru, siswa, dan materi pelajaran.

Untuk memperkuat hasil analisis dekriptif di atas maka uji hipotesis untuk membuktikan hipotesis yang diajukan. Berdasarkan hasil analisis data diperoleh nilai $\mathrm{Z}$ untuk skor keterampilan proses sains sebesar $-4,830$ (berdasarkan tabel Uji Mann Whitney). Dimana nilai $\mathrm{Z}$ tersebut berada pada daerah Ho tolak. Selain itu juga dilakukan pengujian hipotesis yang menggunakan software SPSS dapat diperoleh nilai asymp (2 tailed) menunjukkan p-value untuk keterampilan proses sains. Karena p-value yang diperoleh sebesar $0,000<\alpha=5 \%$ pada skor keterampilan proses sains maka Ho ditolak yang berarti hipotesis diterima. Hal ini menunjukkan bahwa hipotesis penelitian dapat diterima atau berhasil.

Berdasarkan uraian di atas, maka dapat disimpulkan bahwa pembelajaran fisika dengan LKPD inkuiri terbimbing lebih baik dari pada LKPD konvensional. Dengan demikian proses pembelajaran untuk LKPD inkuiri terbimbing dapat memberikan pengaruh dalam pencapaian keterampilan proses sains untuk materi elastisitas pada peserta didik kelas XI SMA Negeri 8 Makassar.

\section{SIMPULAN}

Berdasarkan hasil analisis data dan pembahasan dapat disimpulkan bahwa:

1. Rata-rata skor keterampilan proses sains fisika peserta didik kelas XI SMA Negeri 8 Makassar yang diajar menggunakan pembelajaran inkuiri terbimbing sebesar 11,14 pada tahun 2018/2019.

2. Rata-rata skor keterampilan Proses sains fisika peserta didik kelas XI SMA Negeri 8 Makassar yang diajar menggunakan pembelajaran konvensional sebesar 9,48 pada tahun 2018/2019.

3. Terdapat perbedaan signifikan rata-rata skor keterampilan proses sains antara peserta didik yang diajar menggunakan pembelajaran inkuiri terbimbing dengan peserta didik yang diajar menggunakan pembelajaran konvensional kelas XI SMA Negeri 8 Makassar.

\section{DAFTAR RUJUKAN}

Ambarsari, Wiwin., Santosa, Slamet, Maridi. 2013 Penerapan Pembelajaran Inkuiri Terbimbing Terhadap Keterampilan Proses 
Sains Dasar Pada Pelajaran Biologi Siswa Kelas VIII SMP Negeri 7 Surakarta, Jurnal Pendidikan Biologi, Vol. 5, No 1.

Anam, K. (2015). Pembelajaran Berbasis Inkuiri: Metode dan Aplikasi. Yogyakarta: Pustaka Pelajar.

Arikunto, Suharsini. 2010. Dasar-Dasar Evaluasi Pendidikan. Jakarta: Bumi Aksara.

Aristini, N. K. D., I Komang S., \& Putu N. R. (2017). Pengembangan Lembar Kerja Siswa Berbasis Inkuiri untuk Pemahaman Konsep IPA Siswa Kelas V. e-journal PGSD Universitas Pendidikan Ganesha, Vol. 5, No. 2, 1-12.

Aryawan. 2014. Dasar-Dasar Motivasi Dalam Lingkungan Akademik (Edisi 2) Jakarta: Ghali Indonesia

Asminah, D. R. (2010). Pembelajaran fisika dengan metode inkuiri terbimbing dan inkuiri training ditinjau dari kemampuan awal dan aktifitas siswa. Tesis, tidak dipublikasikan. Universitas Sebelas Maret Surakarta.
Hadma. Y, dkk. 2012. Pemebalajarn fisika dengan pendekatan keterampilan proses sains dengan metode eksperimen dan demonstrasi ditinjau dari sikap ilmiah dan kemampuan analisi. Jurnal iquiri Vol. 1 no 3. Tahun 2012.

Khaeruddin dan Sujiono, E. H. 2005. Pembelajaran Sains (IPA) Berdasarkan Kurikulum Berbasis Kopetensi. Makassar: State university of Makassar Press.

Kristin. S, Desmaria., Nyeneng, I Dewa Putu., Ertikanto, Candra.2015. Pengembangan Model Pembelajaran Berbasis Ikuiri Terbimbing Pada Materi Elastisitas dan Hukum Hooke. Jurnal Pembelajaran Fisika, Vol. 3, No.1

Listyaningrum, Rahmawati Ika., Sajidan., Sucianti. 2012. Penerapan Model Pembelajaran Inductive Thingking Berbasis Keterampilan Proses Sains Untuk Meningkatkan Kualitas Pembelajaran Biologi Siswa Kelas X.7 